\title{
Studies on in vitro antiproliferative activities in Cruciferae vegetables
}

\author{
K.S. Jamuna, M.S. Suma, C.K. Ramesh, Riaz Mahmood' and L. Nanjundaswamy ${ }^{\mathbf{1}}$ \\ Molecular Biomedicine Laboratory, PG Dept. of Studies and Research in Biotechnology, Sahyadri Science College, Kuvempu \\ University, Shimoga - 577203, Karnataka, India. ${ }^{~}$ Department of Postgraduate Studies and Research in Biotechnology \\ and Bioinformatics, Jnana Sahyadri, Kuvempu University, Shimoga 577451, Karnataka, India. ${ }^{2}$ Academic Staff College, \\ University of Mysore, Manasagangotri, Mysore-570006. *E-mail: ckramck@gmail.com
}

\begin{abstract}
Cruciferous vegetables have drawn a great deal of attention in cancer research because of their potential protective properties. In the present study, four vegetables viz. cabbage, cauliflower, kohlrabi and radish were procured and processed for cold extraction procedure using $70 \%$ ethanol. The extracts were subjected to the qualitative phytochemical analysis, quantitative estimation of glucosinolates content and in vitro antiproliferative activity by MTT assay on MCF7, DL and NIH-3T3 cell lines. The results of qualitative phytochemical analysis showed the presence of several bioactive compounds viz. polyphenols, flavonoids, terpenoids, steroids, glycosides and alkaloids. Quantitative estimation of glucosinolates in terms of potassium thiocyanate equivalence $/ 5 \mathrm{mg}$ of extract revealed that the cabbage has highest content of glucosinolate $(122.6 \mu \mathrm{g})$ followed by cauliflower $(109 \mu \mathrm{g})$, kohlrabi $(101.6 \mu \mathrm{g})$ and radish $(60.2 \mu \mathrm{g})$. The four cruciferous vegetables registered notable cell proliferation inhibition at different concentrations $(50,100,200,400$ and $800 \mu \mathrm{g} / \mathrm{mL})$ in a dose dependent manner against three different cell lines. The results of antiproliferative activity was expressed in terms of $\mathrm{IC}_{50}$. Among the four vegetables cabbage showed considerable cytotoxicity and cell proliferation inhibition with an $\mathrm{IC}_{50}$ value of 192.5, 189.7, 589.7 $\mu \mathrm{g} / \mathrm{mL}$ followed by cauliflower $(378.7,398.9,597.9 \mu \mathrm{g} / \mathrm{mL})$, kohlrabi $(389.5,396.9,619.7 \mu \mathrm{g} / \mathrm{ml})$ and radish $(415.4,423.3,703.6 \mu \mathrm{g} /$ $\mathrm{ml}$ ) in three different cell lines MCF7, DL and NIH-3T3, respectively.. The present study underlines the epidemiological surveys that cruciferous vegetables possess anticancer effects might be due to the presence of glucosinolates augmented with other phytochemicals.
\end{abstract}

Key words: Cruciferous vegetables, Phytochemicals, anti-proliferative, MTT, Cell lines

\section{Introduction}

Epidemiological studies have consistently linked abundant consumption of fruits and vegetables lowers the risk of developing several types of cancers (Block et al., 1992, Liu et al., 2002). Cancer is one of the most significant causes of human death. Cruciferous vegetables have drawn a great deal of attention in cancer research because of their potential protective properties (Kim et al., 2009). Various assays are in use to determine the effect of a drug on cells propagated in vitro. They range from simple assays that measure cell viability after drug exposure, i.e. dye exclusion that measures membrane integrity and effect of the drug on cell growth, to other assays that measure cell viability, indirectly, by assessing the ability of the cell to reduce compounds such as MTT, XTT, MTS, SRB, and alamarBlue or to generate ATP (Giuseppe et al., 2006) Perusal of literature related to antioxidant and anticancer properties of cruciferous vegetables reveals that quite number of experimental studies concentrated on antioxidant abilities of different cruciferous vegetables (Ismail Amin and Wee Yee Lee, 2005; Lee Wee Yee et al., 2007; Mohamed Farag and Amira Abdel Motaal, 2010; Joanna Kapusta-Duch et al., 2012). However the studies related to anticancer properties involving different cell lines is rather sporadic and concentrated on individual cruciferous vegetables particularly on broccoli species (Vadivel Subramanian and Gowry, 2011; Renuka Devi and Berla Thangam, 2012; Ashun Chaudhary et al., 2012). Moreover such attempt on Indian context is strangely scanty. Therefore the current study was carried out for antiproliferative activities of four cruciferous vegetables viz. cabbage, cauliflower, kohlrabi and radish were performed by using MTT assay involving cell lines of different origin. The advantages of MTT assay are easy-to-use, safe and has a high reproducibility.

\section{Materials and methods}

Collection of selected cruciferous vegetables: The selected four commonly consumed cruciferous vegetables of tropical India were procured from a local market of Shimoga, Karnataka. The vegetables includes cabbage (Brassica oleracea L. var. capitata L.), cauliflower (Brassica oleracea L. var. botrytis L.), and kohlrabi (Brassica oleracea L.var. gongylodes L.) and radish (Raphanus sativus L.) which were authenticated by the Horticulture Department, Shimoga. The collected materials were processed for extraction procedures.

Extraction: After selection, each vegetable was washed under running tap water followed by washing with distilled water to remove the surface debris. For the cabbage, after wash the outer leaves were removed, the heads divided into four segments and were chopped into small pieces using a cutter. For cauliflower, the heads were obtained by cutting the main stalk. The florets, together with about $1 \mathrm{~cm}$ of the stalk were cut off from the rest of the stalk and used as cauliflower samples. For kohlrabi, the foliage and most external stem layers were removed and the 
remaining edible stem portion was used for the analysis. Further for radish, the leaf portion and the outer most root skin layer were removed and the remaining edible root portion was used for the analysis. Exactly $1 \mathrm{Kg}$ of vegetable was weighed. Finally, the above prepared vegetable sample was chopped into small pieces using cutter and later minced using a mixer grinder and finely macerated. After homogenization, it was extracted in $70 \%$ ethanol for 7 days in dark in the room temperature with intermittent shaking. After 7 days, the whole extract was filtered using muslin cloth at first and then through Whatman No. 1 filter paper and the filtrate was concentrated using rotary evaporator. The yield of crude extract obtained were noted, stored in desiccators for maximum of 3 days; later preserved in deep freezer $\left(-20^{\circ} \mathrm{C}\right)$ for further use (Jamuna et al., 2015).

Qualitative phytochemical analysis: The preliminary qualitative phytochemical studies were performed for testing the different chemical groups present in four cruciferous vegetable extracts (Trease and Evans, 1978; Kokate et al., 1990; Khandelwal, 2006).

Total Glucosinolates: The method of Slominski and Campbell (1989) was used for the analysis of Glucosinolates by thiocyanate ion determination. $10 \mathrm{ml}$ of distilled water was added to $50 \mathrm{mg}$ of each sample after extraction for $30 \mathrm{~min}, 5 \mathrm{ml}$ of $20 \%$ trichloroacetic acid was added to precipitate the protein from the mixtures. The sample mixtures were then centrifuged at $3000 \mathrm{rpm}$ for $10 \mathrm{~min}$ and $3 \mathrm{ml}$ aliquots of supernatant were mixed with $3 \mathrm{ml}$ of $0.4 \mathrm{M}$ $\mathrm{Fe}\left(\mathrm{NO}_{3}\right)_{3}$ in $1 \mathrm{~N} \mathrm{HNO}_{3}$. Two drops of $5 \% \mathrm{HgCl}_{2}$ solution added to one vial to represent the blank sample and the absorbance were read at $460 \mathrm{~nm}$. Potassium thiocyanate is used as a standard and the thiocyanate ion content was calculated using calibration curve. The results are expressed as potassium thiocyanate equivalents in $\mu \mathrm{g} / 5 \mathrm{mg}$ of extract.

In vitro antiproliferative activity: Cytotoxicity of by MTT (3-(4,5-dimethylthiazol-2-yl)-2,5-diphenyl tetrazolium bromide) assay.

Cell culture: Dalton's lymphoma (DL) and NIH-3T3 cell lines of mouse origin; Breast cancer MCF-7 (NCCS, Pune, India) of human origin. The cells were cultured in Dulbecco's modified Eagle's medium (DMEM) supplied with 10\% heat-inactivated FBS (Invitrogen, USA) and 1\% Penicillin-Streptomycin (SigmaAldrich, USA) and $0.37 \%$ sodium bi-carbonate (Sigma-Aldrich, USA) was used at $37^{\circ} \mathrm{C}$ in a $5 \% \mathrm{CO}_{2}$ enriched humidified incubator (Thermo scientific, USA) with $98 \%$ humidity.

Determination of antiproliferative activity by MTT assay: Antiproliferative activity of the extracts against different cell lines was tested using the microtitration colorimetric method of MTT reduction (Mosmann, 1983) with minor modifications as required. MTT is used to determine cell viability in cell proliferation and cytotoxicity assays. Exponential-phase cells that were $80 \%-90 \%$ confluent were harvested from maintenance cultures and counted using a hemocytometer with trypan blue solution. Cell suspensions $(100 \mu \mathrm{l})$ were dispensed in triplicate in 96-well culture plates at optimized concentrations of $\sim 1.0 \times 10^{6}$ cells $/ \mathrm{ml}$ per cancer cell line. After $24 \mathrm{~h}$ incubation at $37^{\circ} \mathrm{C}, 100$ $\mu \mathrm{l}$ culture medium was removed from the wells and $100 \mu \mathrm{l}$ fresh medium containing the extracts $(50,100,200,400,800 \mu \mathrm{g} / \mathrm{mL})$ was added to each well and incubated for another $48 \mathrm{~h}$. Wells containing DMEM were used as the negative controls. At the end of the treatment period, the medium in each well was aspirated and replaced with $5 \mathrm{mg} / \mathrm{mL}$ of MTT reagent. The cells were incubated at $37^{\circ} \mathrm{C}$ for $4 \mathrm{~h}$, and then the medium was aspirated and replaced with $100 \mu \mathrm{l}$ DMSO to dissolve the formazan crystals formed. The cells were incubated for $10 \mathrm{~min}$ and the absorbance (OD) of each well was read using micro-ELISA reader (Robonics, India) at $570 \mathrm{~nm}$. The results were produced from three independent experiments, and each experiment was performed in triplicate for each cell line. The cytotoxicity was evaluated and confirmed by comparing the absorbance between the samples and the control blank. The values were then used to determine the $\mathrm{IC}_{50}$ of plant extract i.e., concentration required to cause a $50 \%$ reduction $\left(\mathrm{IC}_{50}\right)$ in growth (cell number) for each cell line. Percent of cell inhibition was determined using following formula,

$\%$ inhibition $=\left[\left(\mathrm{A}_{\text {control }}-\mathrm{A}_{\text {test }}\right) / \mathrm{A}_{\text {control }}\right] \times 100$

Where, $\mathrm{A}_{\text {control }}$ is the absorbance of the control reaction and $\mathrm{A}_{\text {test }}$ is the absorbance of the extract reaction.

Statistical analysis: All the experiments were performed in triplicate and results are recorded as mean \pm SEM. Data were analyzed by one way analysis of variance (ANOVA) and a significant difference among treatment groups were evaluated by Duncan's Multiple Range Test (DMRT). The results were considered statistically significant at $P$ value less than 0.05 . All statistical analyses were made using SPSS 16.0 software.

\section{Results}

Extraction: The extraction of bioactive compounds from plant materials is the first step in the utilization of phytochemicals in the preparation of dietary supplements or nutraceuticals, food ingredients, pharmaceutical products. Results of the present study revealed that cabbage showed high percentage yield $(56.28 \mathrm{~g})$ followed by kohlrabi $(50.85 \mathrm{~g})$, radish $(49.85 \mathrm{~g}$ ) and cauliflower $(44.13 \mathrm{~g})$ per $\mathrm{kg}$ fresh weight of plant material.

Qualitative phytochemical analysis: The results of qualitative phytochemical analysis of four cruciferous vegetable ethanolic extracts showed the presence of several bioactive compounds viz. polyphenols, flavonoids, terpenoids, steroids, glycosides and alkaloids. Saponins were present in cabbage and radish extracts while absent in cauliflower and kohlrabi extracts (Table 1).

Table 1. Qualitative phytochemical analysis of Cruciferous vegetable extracts

\begin{tabular}{lcccc}
\hline Tests & cabbage & cauliflower & kohlrabi & radish \\
\hline Steroids & + & + & + & + \\
Glycosides & + & + & + & + \\
Terpenoids & + & + & + & + \\
Saponins & + & - & - & + \\
Alkaloids & + & + & + & + \\
Flavonoids & + & + & + & + \\
Tannins and Polyphenols & + & + & + & + \\
\hline
\end{tabular}

Total Glucosinolates: The total glucosinolates of the four cruciferous vegetable extracts were compared with standard curve of potassium thiocyanate and the results were expressed as the number of equivalents of potassium thiocyanate $(\mu \mathrm{g} / 5 \mathrm{mg}$ of extract). The result revealed that cabbage showed the highest of glucosinolate content $(122.6 \mu \mathrm{g})$ followed by cauliflower (109 $\mu \mathrm{g})$, kohlrabi $(101.6 \mu \mathrm{g})$ and radish $(60.2 \mu \mathrm{g})$. The results were presented in Fig 1. 

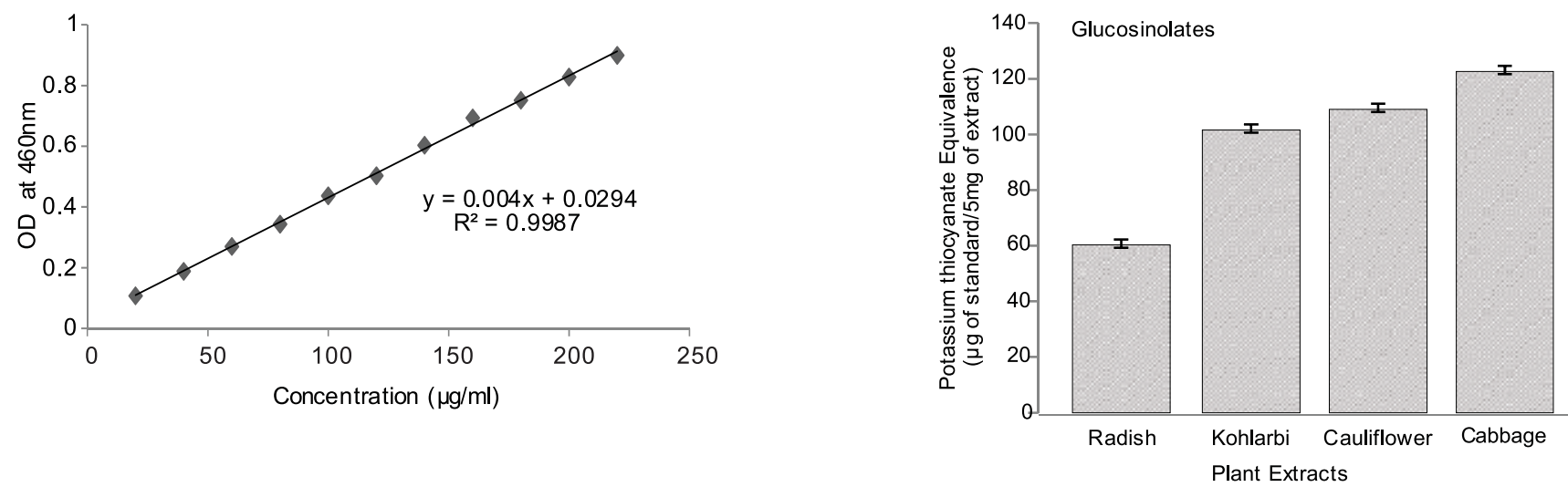

Fig. 1. Total Glucosinolates in four Cruciferae vegetable extracts

Determination of antiproliferative activity by MTT assay: The results of antiproliferative activity of cruciferous vegetables at different concentrations $(50,100,200,400$ and $800 \mu \mathrm{g} / \mathrm{mL})$ against MCF7, DL and NIH-3T3 in terms of $\mathrm{IC}_{50}$ were depicted in Fig. 2. The results revealed that the cruciferous vegetable extracts inhibited cell proliferation in a dose dependent manner. Extracts of cabbage showed considerable cytotoxicity and cell proliferation inhibition in MCF7 cell line with an $\mathrm{IC}_{50}$ value of $192.5 \mu \mathrm{g} / \mathrm{mL}$, followed by cauliflower $(378.7 \mu \mathrm{g} / \mathrm{mL})$, kohlrabi $(389.5 \mu \mathrm{g} / \mathrm{mL})$ and radish $(415.4 \mu \mathrm{g} / \mathrm{mL})$ extracts. Similarly for DL cell line, cabbage extract has shown appreciable cell proliferation inhibition with an $\mathrm{IC}_{50}$ of $189.7 \mu \mathrm{g} / \mathrm{mL}$ kohlrabi $396.9 \mu \mathrm{g} / \mathrm{mL}$, cauliflower $398.9 \mu \mathrm{g} / \mathrm{mL}$ and radish $423.3 \mu \mathrm{g} / \mathrm{mL}$. Further for NIH-3T3 cell line, cabbage, cauliflower, kohlrabi and radish extracts have recorded 589.7, 597.9, 619.7 and 703.6 $\mu \mathrm{g} /$ $\mathrm{mL}$ of $\mathrm{IC}_{50}$, respectively.

From the results, it is imperative that all the four cruciferous vegetable extracts have showed cell proliferation inhibition against three cell lines of diverse origin. Among the selected vegetables, cabbage extract has been observed to be the most effective against three cell lines in showing antiproliferative activity followed by cauliflower, kohlrabi and radish. The antiprolifrative or cytotoxicity of cabbage extracts against the three cell lines under study was found to be in the order of MCF7 $>$ DL $>$ NIH-3T3. It is interesting to note that, there is a positive correlation between the cruciferous vegetable with higher amount of glucosinolates has greater antiproliferative activity.

\section{Discussion}

The consumption of fruits and vegetables are an essential part of balanced diet and has been associated with low incidences and mortality rates of cancer (Ames et al. 1993; Dragsted et al.1993). This association of promoting human health is often attributed to the presence of phytonutrients (Cao et al. 1997; Prior and Cao, 2000). Therefore, they have been regarded as potential cost-effective natural chemotherapeutic agents with minimal side effects. In contrast, the conventional cancer treatment (surgical removal and chemotherapy) have serious side effects and morbidity (Kim et al., 2013).

In the present study, four different cruciferous vegetables viz. cabbage, cauliflower, kohlrabi and radish recorded the presence for several bioactive compounds viz. polyphenols, flavonoids, terpenoids, steroids, glycosides and alkaloids. Pertinent literature survey suggest that, phytochemicals from cruciferous vegetables induce detoxification enzymes, scavenge free radicals, alleviate inflammation, stimulate immune functions, decrease the risk for cancers, inhibit malignant transformation and regulate the growth of cancer cells (Herr and Buchler, 2010).

Testing the effects of compounds on the viability of cells grown in culture is widely used as a predictor of potential toxic effects in whole animals. Among the several assays available, measuring the levels of ATP is the most sensitive, reliable, and convenient method for monitoring active cell metabolism (Terry et al., 2011). In the present study, MTT assay is used to determine the in vitro antiproliferative activity or cytotoxicity of four Cruciferae vegetable extracts against NIH-3T3, DL and MCF7 cells. MTT assay is a rapid and high accuracy colorimetric approach that widely used to determine cell viability, cell

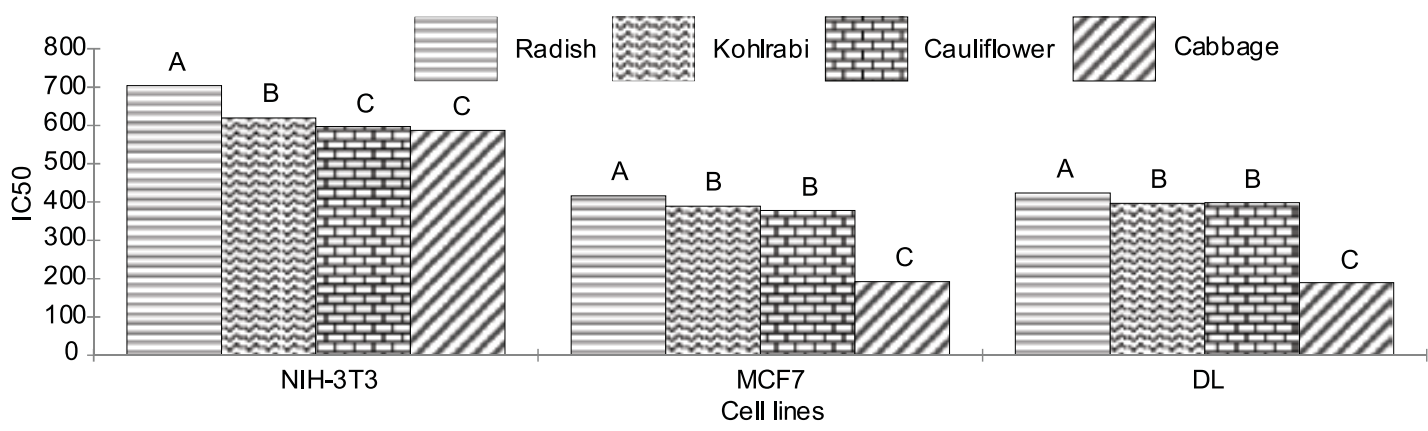

Fig 2. Antiproliferative effect in $\mathrm{IC}_{50}$ values of four cruciferous vegetables against different cell lines. Cytotoxicity was measured by MTT assay against each cell lines in three independent experiments $(n=3)$ for each sample. Values are indicated in mean \pm SEM and statistically significance were evaluated by DMRT analysis. 
growth and cell cytotoxicity, particularly in the development of new drug. Among the enzyme-based assays, the MTT assay is the best known method as it measures cell membrane integrity by determining mitochondrial dehydrogenase activities in the living cells on the reduction of MTT to a purple formazan by NADH (Nor Azurah Mat Akhir et al. 2011). The 3T3 cell line is the standard fibroblast immortal cell line originally obtained from Swiss albino mouse embryo tissue (George Todaro and Howard Green, 1963). MCF-7 breast cancer cells serve as an excellent in vitro model for studying the mechanism of tumor response as well as complex relationships between binding and biological actions of hormones (Dillon et al., 2010). DL cell line is a lymphoma caused in the murine lymphatic system. Hence, this tumour cell line is reliable model for screening the potent cytotoxic molecule (Nagy et al.,1995). Our observations on cytotoxicity of cruciferous vegetable extracts have showed notable cell proliferation inhibition activity in three different cell lines of different origin. Among the four selected vegetables, cabbage showed most effective antiproliferative activity followed by cauliflower, kohlrabi and radish. While among the three cell lines tested, significant antiproliferative activity was noted in the breast cancer carcinoma cell line, MCF7 followed by Dalton's Lymphoma of murine origin, DL and normal immortal fibroblast cell line, NIH-3T3 indicating their efficacy.

The qualitative analysis of all the four vegetable extracts showed protective phytochemicals including phenols, flavonoids etc. Consumption of foods that contain phenolics and flavonoids has been shown to reduce the risk of cancer (Kanadaswami et al., 2005; Ramos et al., 2005; Suleria et al., 2015). In addition, several studies have indicated high cytotoxic and anticancer activity of flavonoids (Canadanovic-Brunet et al., 2008; Hui et al., 2013; Liu et al., 2014; Guercio et al., 2016). Flavonoid anticancer activities include inhibition of cell growth, inhibition of protein kinase activities, induction of apoptosis (Mosmann, 1983; Wenzel et al., 2000; Yamazaki et al., 2014; Ren et al., 2015). Furthermore, the interest in food with chemoprotective properties has been steadily increasing due to many epidemiological studies indicating the lower probability of acquiring some kinds of cancer in populations, whose diet includes large quantities of Cruciferae vegetables. It is also evident in the study that the glucosinolates content in the vegetables are positively correlated with the antiproliferative activity. Secondary plant products and especially breakdown products of glucosinolates including isothiocyanates, nitriles, thiocyanates, indoles from vegetables of the Cruciferae family are supposed to have anti-carcinogenic potentials (Delonga et al., 2007). Isothiocyanates are reported to possess multiple anticarcinogenic mechanisms, including inhibition of carcinogen activating enzymes, induction of carcinogen detoxifying enzymes, increase of apoptosis, arrest of cell cycle progression, as well as several other mechanisms related to anticancer effects (Yuesheng Zhang, 2004). The significant antiproliferative activity of the cruciferous vegetables might be primarily due to the presence of these derivatives of glucosinolates augmented with other phytochemicals and therefore the present study underlines the epidemiological surveys that cruciferous vegetables possess anticancer effects.

On the basis of the results obtained in the present study, it is concluded that crucifeorus vegetables exhibited significant in vitro antiproliferative activities against the three cell lines under study. Further research is underway to purify and characterize the glucosinolates (biologically active substances) from these vegetables and to evaluate these phytochemicals as nutraceuticals after the detailed examination of the effects of these agents on cell lines in vivo.

\section{Acknowledgement}

The authors are thankful to the UGC, India for financial assistance under the major research project and Prof. Vadlapudi Kumar, Davangere University for help in editing the manuscript.

\section{References}

Ames, B.M., M.K. Shigenaga and T.M. Hagen, 1993. Oxidants, antioxidants and the degenerative diseases of aging. Proc. Natl. Acad. Sci., 90: 7915- 7922.

Ashun Chaudhary., Geetanjali Rampal., Upendra Sharma., Tarunpreet Singh Thind., Bikram Singh., Adarsh Pal Vig and Saroj Arora, 2012. Anticancer, antioxidant activities and GC-MS analysis of glucosinolates in two cultivars of broccoli. J. med. chem. drug discov., 2(2): 30-37.

Block, G., B. Patterson and A. Subar, 1992. Fruit, vegetables, and cancer prevention: a review of the epidemiological evidence. Nutr. Cancer., 8(1): 1 - 29 .

Canadanovic Brunet, J., G. Cetkovic, S. Dilas, V. Tumbas, G. Bogdanovic, A. Mandic, S. Markov, D. Cvetkovic and V. Canadanovic, 2008. Radical scavenging, antibacterial, and antiproliferative activities of Melissa officinalis L. extracts. J. Med. Food., 11: 133- 143.

Cao, G., E. Sofic and R.L. Prior, 1997. Antioxidant and prooxidant behavior of flavonoids: structure activity relationships, Free Radicals Biol. Med., 22: 749- 760.

Delonga, K., I. Radojcic, V. Dragovic Uzelac, V. Mrkic and J. VorkapicFurac, 2007. Distribution of glucosinolates in some raw and processed Brassica vegetables grown in Croatia, Acta. Aliment. Hung., 36 (2): 207- 216.

Dillon, D.A., A.J. Guidi and S.J. Schnitt, 2010. Chapter 28: Pathology of Invasive Breast Cancer, in Harris, J.R., M.E. Lippman, M. Morrow, C.K. Osborne, Diseases of the Breast, Fourth edition, Lippincott Williams and Wilkins.

Dragsted, L.O., M. Strube and J.C. Larsen, 1993. Cancer-protective factors in fruits and vegetables: biochemical and biological background, Pharmacol. Toxicol., 72: 116- 135.

George J. Todaro and M.D. Howard Green, 1963. Quantitative studies of the growth of mouse embryo cells in culture and their development into established lines.J. Cell Biol., 17: 219-313.

Giuseppe S. A., Longo Sorbello, Guray Saydam, Debabrata Banerjee and Joseph R. Bertino, 2006. Cytotoxicity and Cell Growth Assays, Cell biology: A Laboratory Handbook, Third edition, 315- 325.

Guercio, V., F. Turati, C. La Vecchia, C. Galeone and A. Tavani, 2016. Allium vegetables and upper aerodigestive tract cancers: a metaanalysis of observational studies. Mol. Nutr. Food Res., 60(1): 212-222.

Herr, I and M.W. Buchler, 2010. Dietary constituents of broccoli and other cruciferous vegetables: Implications for prevention and therapy of cancer. Cancer. Treat. Rev., 36(5): 377- 383.

Hui, C., X. Qi, Z. Qianyong, P. Xiaoli, Z. Jundong and M, Mantian, 2013. Flavonoids, Flavonoid Subclasses and Breast Cancer Risk: A Meta-Analysis of Epidemiologic Studies. PLoS ONE, 8(1).

Ismail Amin and Wee Yee Lee, 2005. Effect of different blanching times on antioxidant properties in selected cruciferous vegetables, J. Sci. Food Agric., 85:2314-2320.

Jamuna, K.S., C.K. Ramesh, Riaz Mahmood, M. Pallavi and S.J. Aditya Rao, 2015. Effect of different extraction methods on total phenolic content and antioxidant activities of Raphanus sativus L., Int. J. Bioassays., 4(12): 4653- 4657. 
Joanna Kapusta-Duch., Teresa Leszczyńska., Agnieszka FilipiakFlorkiewicz, 2012. Comparison of total polyphenol contents and antioxidant activity in cruciferous vegetables grown in diversified ecological conditions. Acta Sci. Pol., Tech. Aliment. 11(4): 335-346.

Kanadaswami, C., L.T. Lee, P.P.H. Lee, J.J. Hwang, F.C. Ke, Y.T. Huang and M.T. Lee, 2005. The antitumor activities of flavonoids. In vivo., 19: 895- 909 .

Khandelwal, K.R., 2006. Practical Pharmacognosy techniques and experiments, Sixteenth edition, Nirali Prakashan, Pune, 149- 156.

Kim, E.K, Y.S. Kim, J.W. Hwang, J.S. Lee, S.H. Moon, B.T. Jeon, et al., 2013. Purification and characterization of a novel anticancer peptide derived from Ruditapes philippinarum. Process Biochem., 48: 1086- 90.

Kim, M.K., J.H. Park, 2009. In: Conference on 'multidisciplinary approaches to nutritional problems, Symposium on 'nutrition and health, Cruciferous vegetable intake and the risk of human cancer: epidemiological evidence. Proc. Nutr. Soc., 68: 103- 10.

Kokate, C.K., A.P. Purohith and S.B. Gokhale, 1990. Pharmacognosy, Nirali Prakashan Pune, 120.

Lee Wee Yee., Emmy Hainida Khairul Ikram., Abbe Maleyki Mhd Jalil and Amin Ismail, 2007. Antioxidant Capacity and Phenolic Content of Selected Commercially Available Cruciferous Vegetables. Mal. J. Nutr, 13(1): 71-80.

Liu, M., X.Q. Li, C. Weber, C.Y. Lee, J. Bron and R.H. Liu, 2002. Antioxidant and antiproliferative activities of raspberries, J. Agric. Food. Chem., 50: 2926- 2930.

Liu, Y. J. Zhan, X. Liu, Y. Wang, J. Ji and Q. He, 2014. Dietary flavonoids intake and risk of type 2 diabetes : A meta-analysis of prospective cohort studies. Clin. Nutr., 33(1), 59-63.

Mohamed, A. Farag., Amira, A. Abdel Motaal, 2010. Sulforaphane composition, cytotoxic and antioxidant activity of crucifer vegetables, J. Adv. Res., 1(1): 65-70.

Mosmann, T., 1983. Rapid colorimetric assay for cellular growth and survival: Application to proliferation and cytotoxicity assays, $J$. Immunol. Methods., 65: 55- 63.

Nagy, J.A., E.S. Morgan, K.T. Herzberg, E.J. Manseau, A.M. Dvorak and H.F. Dvorak, 1995. Pathogenesis of ascites tumor growth: Angiogenesis, vascular remodeling, and stroma formation in the peritoneal lining. Cancer. Res., 55: 376- 385.

Nor Azurah Mat Akhir, Lee Suan Chua, Fadzilah Adibah Abdul Majid and Mohamad Roji Sarmidi, 2011. Cytotoxicity of aqueous and ethanolic extracts of Ficus deltoidea on human ovarian carcinoma cell line, Br. J. Med. Med. Res., 1(4): 397- 409.
Prior, R. L and G.H. Cao, 2000. Analysis of botanicals and dietary supplements for antioxidant capacity: A review, J. AOAC. Int., 83: 950- 956

Ramos, S., M. Alia, L. Bravo and L. Goya, 2005. Comparative effects of food-derived polyphenols on the viability and apoptosis of a human hepatoma cell line (HepG2). J. Agric. Food Chem., 53: 1271- 1280.

Ren, M. X., X. Deng, F. Ai, G. Yuan and H. Song,2015. Effect of quercetin on the proliferation of the human ovarian cancer cell line SKOV-3 in vitro. Exp. Ther. Med., 10(2): 579-583.

Renuka Devi, J and E. Berla Thangam, 2012. Mechanisms of Anticancer Activity of Sulforaphane from Brassica oleracea in HEp-2 human epithelial carcinoma cell line. Asian Pac. J. Cancer Prev., 13: 2095-2100.

Slominski, B.A and L.D. Campbell, 1989. Indoleacetonitriles-Thermal degradation products of indole glucosinolates in commercial rapeseed (Brassica napus) meal. J. Sci. Food Agric., 47, 75- 84.

Suleria, H. A. R., M. S. Butt, F. M. Anjum, F. Saeed and N. Khalid, 2015. Onion: Nature Protection Against Physiological Threats. Crit. Rev. Food Sci. Nutr., 55, 50-66.

Terry L. Riss., Richard A. Moravec and Andrew L. Niles, 2011. Cytotoxicity Testing: measuring viable cells, dead cells, and detecting mechanism of cell death, Methods Mol. Biol., 740: 103- 114.

Trease, G. E., and W.C. Evans, 1978. A Text book of Pharmacognosy, Eleventh edition. Bailliere Tidall, London, 530.

Vadivel Subramanian., S. Gowry., 2011. Antitumor Activity and Antioxidant Role of Brassica oleracea Italica against ehrlich ascites Carcinoma In Swiss Albino Mice. Res. J. Pharm., Biol. Chem. Sci., 2(3): 275-285.

Wenzel, U., S. Kuntz, M.D. Brendel and H. Daniel, 2000. Dietary Flavone Is a Potent Apoptosis Inducer in Human Colon Carcinoma Cells. Cancer Res., (60)14: 3823-3831.

Yamazaki, S., N. Miyoshi, K. Kawabata, M. Yasuda and K. Shimoi, 2014. Quercetin-3-O-glucuronide inhibits noradrenaline-promoted invasion of MDA-MB-231 human breast cancer cells by blocking 32-adrenergic signaling. Arch. Biochem. Biophys., 557, 18-27.

Yuesheng Zhang, 2004. Cancer-preventive isothiocyanates: measurement of human exposure and mechanism of action, Mutat. Res., 555(12): $173-90$. 